\title{
INFLUENCE OF REINFORCEMENT ON THE BEHAVIOR OF HOLLOW CONCRETE BLOCK MASONRY PRISM UNDER COMPRESSION- AN EXPERIMENTAL AND ANALYTICAL APPROACH
}

\author{
Sandeep $^{1}$, M V Renukadevi ${ }^{2}$, Manjunath $^{3}$, Somanath ${ }^{4}$ \\ ${ }_{1,2,3,4}$ Mtech student, Department of Civil Engineering, R.V College of Engineering, Bangalore-560059 \\ sandeepdb222@gmail.com
}

\begin{abstract}
Reinforced masonry was developed to exploit the strength potential of masonry and to solve its lack of tensile strength. Experimental and analytical studies have been carried out to investigate the effect of reinforcement on the behavior of hollow concrete block masonry prisms under compression and to predict ultimate failure compressive strength. In the numerical program, three dimensional non-linear finite elements (FE) model based on the micro-modeling approach is developed for both unreinforced and reinforced masonry prisms using ANSYS (14.5). The proposed FE model uses multi-linear stress-strain relationships to model the non-linear behavior of hollow concrete block, mortar, and grout. Willam-Warnke's five parameter failure theory has been adopted to model the failure of masonry materials. The comparison of the numerical and experimental results indicates that the FE models can successfully capture the highly nonlinear behavior of the physical specimens and accurately predict their strength and failure mechanisms.
\end{abstract}

Keywords: Structural masonry, Hollow concrete block prism, grout, Compression failure, Finite element method, Numerical modeling.

\section{INTRODUCTION}

Masonry is a highly durable material used in construction for thousands of years. Masonry elements are relatively quick to construct and low in cost, and have a pleasing aesthetic appearance. Since early in the 20th century, it is commonly accepted that Unreinforced Masonry (URM) structures are the most vulnerable during earthquakes. The poor performance of URM structures subjected to lateral loads is due to insufficient shear and flexural capacity. In order to improve the performance of URM structures especially walls the reinforcement can be introduced in hollow concrete block to resist in-plane seismic forces resulting from earthquakes.

In the past few decades variety of reinforced masonry techniques have been proposed. The various masonry systems depend on many parameters such as geometric shapes and material of masonry unit, composition of mortar and grout, quantity and layout of reinforcement. Most of the reinforced masonry systems around the world are based on the use of hollow concrete units; introduction of steel reinforcement ensures an increase of ductility and provide better energy dissipation under seismic loading.

Here an attempt has been made to develop a three dimensional non linear FE models to predict masonry behavior under axial compression. Non-linear analysis is carried out using finite element software ANSYS 14.5. FE models are developed for both unreinforced and reinforced hollow concrete block masonry prisms. The FE model is validated by comparing the predicted value with the experimental results.

\section{EXPERIMENTAL PROGRAMME}

The experimental studies were carried out to obtain information on the following aspects

(i) Compressive strength and stress-strain characteristics of the hollow concrete block, mortar, and grout.

(ii) Compressive strength and stress strain characteristics of URM and RM prisms.

\subsection{Hollow Concrete Blocks}

In the present study locally available hollow concrete blocks from standard manufacturer of size $400 \times 200 \times 190 \mathrm{~mm}$ were used. The compressive strength, water absorption, and initial rate of absorption (IRA) was determined by following the guidelines of IS: 2185 part 1- 1979[10]. The stress strain relationship for the block was obtained by testing them in a compression testing machine. Mean values of net compressive strength, water absorption, and IRA for these blocks were 14 $\mathrm{MPa}$ and $5.02 \%, 0.7235 \%$ respectively. The Young's modulus at $30 \%$ of peak stress was found to be $14393.5 \mathrm{MPa}$. 


\subsection{Cement-sand Mortar}

Cement-sand mortar of mix 1:6 by volume was used in this investigation. Grade 53 ordinary Portland cement conforming to IS:2250-1981[11] and river sand were used. Consistency of mortar was determined by flow table test according to IS:5512-1969[] and the w/c of 1.27 was adopted for flow of $100 \%$. Compressive strength of mortar was obtained by testing $50 \mathrm{~mm}$ mortar cube under compression testing machine. Mean compressive strength of the mortar obtained was 6.5 MPa. The stress-strain relationship for mortar was obtained by testing mortar cylinders of size $150 \mathrm{~mm}$ diameter and $300 \mathrm{~mm}$ height. The Young's modulus at $30 \%$ of peak stress was found to be $12500 \mathrm{MPa}$.

\subsection{Grout}

Grout for masonry construction is a high slump mixture of cementitious materials, aggregate, and water. Grout is used to fill cells in hollow masonry units to increase capacity and hold reinforcing steel in place. Grout has a maximum aggregate size of $12.5 \mathrm{~mm}$ and the slump should be between 200 and 250 $\mathrm{mm}$ [6]. In the present investigation M20 grade concrete was used as a grout with a slump value of 220 and water-cement ratio of 0.75 , and maximum aggregate size of $12.5 \mathrm{~mm}$ was considered. The mean compressive strength of grout obtained was $23 \mathrm{MPa}$. The stress-strain relationship for grout was obtained by testing grout cylinder of size $150 \mathrm{~mm}$ diameter and $300 \mathrm{~mm}$ height. The Young's modulus at $30 \%$ of peak stress for the grout was found to be $27700.93 \mathrm{MPa}$.

\subsection{Reinforcement}

Reinforcement is used in the masonry structures to resist tensile and shear stresses induced by various load conditions, to increase axial load carrying capacity, and to provide ductility under seismic loading. Steel employed as reinforcement in masonry structures includes reinforcing bars, joint reinforcement, connectors, and pre-stressing steels. In this study reinforcement were provided following the guidelines of IITK-GSDMA [13]. Grade Fe 415 reinforcing bars of diameter $12 \mathrm{~mm}$ were provided at every corner of the block and which is tied with the help of stirrups of diameter 8 mm bars.

\subsection{Compressive Strength of the Masonry Prism}

The compressive strength of masonry prisms were determined by testing the stack bonded masonry prisms. The three block height URM and RM masonry prisms were casted using hollow concrete blocks and mortar joint thickness of $15 \mathrm{~mm}$ were used. The prisms were cured for a period of 28 days under moist burlap. The tests were carried out in a compression testing machine. The mean compressive strength of URM and RM prisms was found to be 5.43 and $8.3 \mathrm{MPa}$ respectively.

\section{FINITE ELEMENT ANALYSIS BY ANSYS (14.5)}

Finite element analysis were performed using the ANSYS (14.5) software to investigate the behavior of masonry prisms under compression and to predict the ultimate failure compressive stress .In this study three block height masonry prisms of size $400 \times 200 \times 600 \mathrm{~mm}$ with $15 \mathrm{~mm}$ mortar joint thickness were considered for analysis. The masonry prisms were modeled using the micro-modeling approach.

\subsection{Masonry Unit, Mortar and Grout Modeling:}

An eight-node solid element (SOLID65) was used to model the hollow concrete block, mortar, and grout. The solid element has eight nodes with three degrees of freedom at each node, translations in the nodal $\mathrm{x}, \mathrm{y}$, and $\mathrm{z}$ directions. The element is capable of plastic deformation, cracking in three orthogonal directions and crushing. The Solid 65 element requires linear isotropic and multi-linear isotropic material properties to properly model concrete element (masonry unit, mortar, grout) as can be seen in table 1 .

\subsection{Reinforcement Modeling}

3-D spar element (Link 180) was used to model the reinforcement. This element has two nodes and three degrees of freedom for each node, translations in the nodal $\mathrm{x}, \mathrm{y}$, and $\mathrm{z}$ directions. The bilinear kinematic hardening model was used, it requires the yield stress ( $f y)$ and the hardening modulus of the steel $\left(\mathrm{E}_{\mathrm{s}}\right)$. Yield stress of $415 \mathrm{MPa}$, elastic modulus of $2 \times 10^{-5} \mathrm{MPa}$ and Poisson's ratio of 0.3 were used.

Table 1: Linear and multi linear material properties for solid65

\begin{tabular}{|c|c|c|c|}
\hline \multicolumn{4}{|l|}{ Linear Isotropic } \\
\hline Material property & $\begin{array}{l}\text { Masonry } \\
\text { unit }\end{array}$ & $\begin{array}{l}\text { Mortar } \\
\text { joint }\end{array}$ & Grout \\
\hline Young's Modulus, E (MPa) & $14,393.5$ & 12500 & 27700 \\
\hline Poisson's ratio, $v$ & 0.18 & 0.16 & 0.18 \\
\hline
\end{tabular}




\begin{tabular}{|c|c|c|c|c|c|}
\hline \multicolumn{6}{|c|}{ Multi-linear Isotropic } \\
\hline \multicolumn{2}{|c|}{ Hollow concrete block } & \multicolumn{2}{|c|}{ Cement-sand mortar(1:6) } & \multicolumn{2}{|c|}{$\begin{array}{l}\text { Grout -M20 concrete } \\
(1: 1.5: 3)\end{array}$} \\
\hline Strain & $\begin{array}{l}\text { Stress } \\
\text { Mpa }\end{array}$ & Strain & $\begin{array}{l}\text { Stress } \\
(\mathrm{MPa})\end{array}$ & Strain & $\begin{array}{l}\text { Stress } \\
(\mathrm{Mpa})\end{array}$ \\
\hline 0.0002 & 2.8787 & 0.00005 & 0.625 & 0.00008 & 2.2160 \\
\hline 0.0004 & 4.9750 & 0.0001 & 1.236 & 0.00016 & 4.3064 \\
\hline 0.0006 & 6.7097 & 0.00015 & 1.858 & 0.00024 & 5.9410 \\
\hline 0.0008 & 8.0582 & 0.0002 & 2.301 & 0.00032 & 7.3932 \\
\hline 0.001 & 9.2236 & 0.00025 & 2.819 & 0.0004 & 8.5500 \\
\hline 0.0012 & 9.5528 & 0.0003 & 3.243 & 0.00048 & 9.9582 \\
\hline 0.0014 & 10.4191 & 0.00035 & 3.627 & 0.00056 & 11.454 \\
\hline 0.0016 & 10.9227 & 0.0004 & 4.026 & 0.00064 & 12.573 \\
\hline 0.0018 & 11.2015 & 0.00045 & 4.380 & 0.00072 & 13.626 \\
\hline 0.002 & 11.4805 & 0.0005 & 4.411 & 0.0008 & 14.478 \\
\hline 0.0022 & 12.4440 & 0.00055 & 4.666 & 0.00088 & 15.2344 \\
\hline 0.0024 & 12.6960 & 0.0006 & 4.869 & 0.00096 & 14.3433 \\
\hline
\end{tabular}

Implementation of the Willam and Warnke [8] material model in ANSYS requires different constants to be defined in table 2

Table 2: Concrete constants for solid 65

\begin{tabular}{|l|l|l|l|}
\hline Material property & $\begin{array}{l}\text { Masonry } \\
\text { unit }\end{array}$ & $\begin{array}{l}\text { Mortar } \\
\text { joint }\end{array}$ & Grout \\
\hline Shear transfer coefficient for open crack, $\beta_{\mathrm{t}}$ & 0.3 & 0.3 & 0.3 \\
\hline Shear transfer coefficient for close crack, $\beta_{\mathrm{c}}$ & 0.6 & 0.6 & 0.6 \\
\hline Uniaxial cracking stress ft (Mpa) & 1.2 & 0.6 & 2.3 \\
\hline Uniaxial crushing stress fc (Mpa) & 12 & 6 & 23 \\
\hline
\end{tabular}

The shear transfer coefficient $\beta$ represents conditions of the crack face. The value of $\beta$ ranges from 0 to 1 , with 0 representing a smooth crack (complete loss of shear transfer) and 1 representing a rough crack (no loss of shear transfer). In this study the shear transfer coefficient was taken as 0.3 for open crack and 0.6 for closed crack.

\subsection{Finite Element Discretisation}

Finite element analysis requires meshing of the model as shown in fig. 6 and the reinforcement details of FE model is shown in fig.7. The prism is constrained at base as simply supported. The surface pressure was applied onto the prism in sub-steps and non-linear analysis was carried out until convergence of the solution was achieved. 


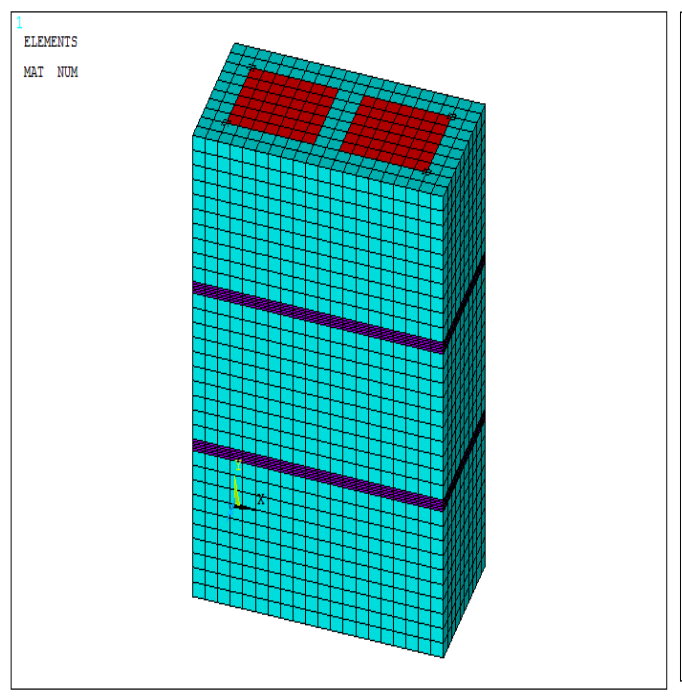

Fig. 6: FE model and boundary conditions

\subsection{Crack Patterns}

Figure 8 (a) shows the crack pattern of FE model at the centroid of the element which was found comparable with the experimental observation figure 8 (b).

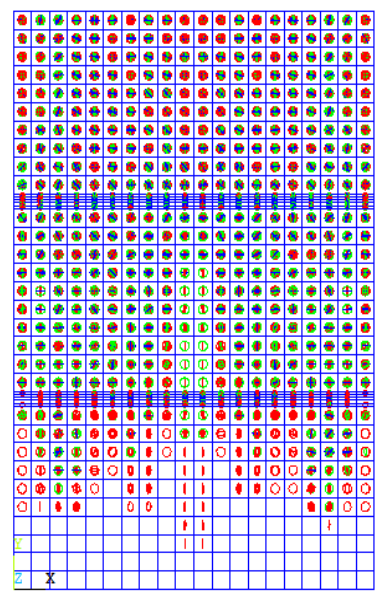

(a) F.E.M

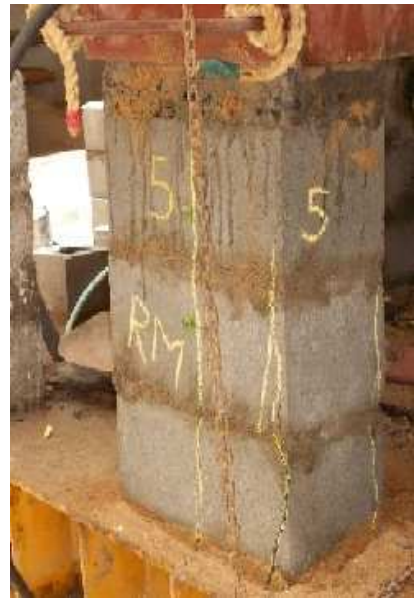

(b) Experimental
Fig. 8 crack pattern in the RM prism

\section{CONCLUSIONS}

The experimental and analytical study shows that introduction of reinforcement in hollow concrete block increases the axial load carrying capacity of the prism and also increases ductility. The FE model successfully predicts ultimate failure compressive stress of URM and RM prism close to $85 \%$ of the experimental values.

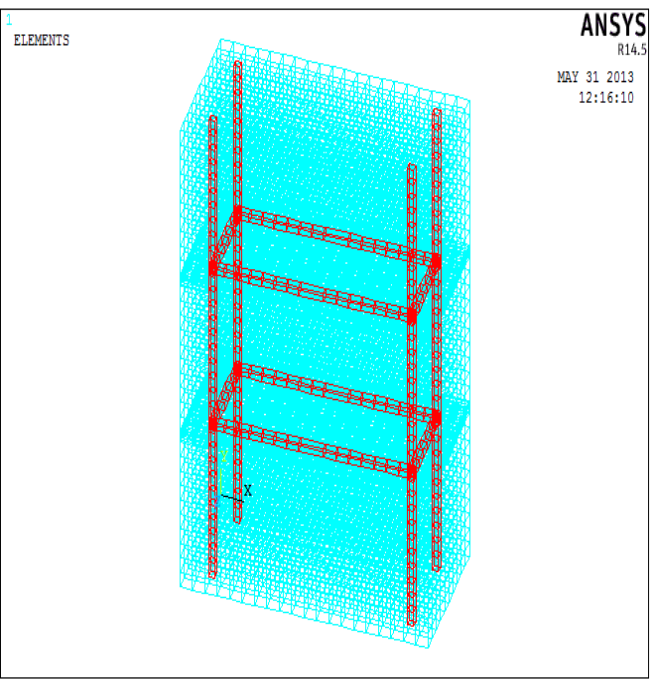

Fig. 7: Reinforcement details of FE model

\section{REFERENCES}

[1] Cheema TS, Klingner RE. Compressive strength of concrete masonry prisms. American Concrete Institute. ACI Struct J 1986; 83(1):88-97. January-February.

[2] Francesca da Porto, Flavio Mosele, Claudio Modena (2010). "Experimental testing of tall reinforced masonry walls under out-of-plane actions". Department of Structural and Transportation Engineering, University of Padova, Italy.

[3] V.Uday Vyas, B.V.Venkatarama Reddy (2010). Prediction of solid block masonry prism compressive strength using FE model. Department of Civil Engineering, Indian Institute of Science, Bangalore 560012, India.

[4] Gihad Mohamad, Paulo B. Lourencco, Humberto R. Roman (2006) Mechanics of hollow concrete block masonry prisms under compression: Review and prospects. Department of Civil Engineering, University of Minho, Azure'm, 4800-058 Guimarães, Portugal.

[5] Farhad Afshari and Movses J. Kaldjian (1989) Finite element analysis of concrete masonry prism. ACI materials Journal, Vol 86, No. 5, September-October 1989.

[6] Khalaf FM, Hendry AW, Fairbairn DR. Study of the compressive strength of block work masonry. Struct J, ACI 1994; 94(4):365-75.

[7] A. M. Fathy, J. Planas, J. M. Sancho (2007) a numerical study of masonry cracks. Faculty of Engineering, Ain Shamas University, Cairo, Egypt.

[8] K. J. William and E. D. Warnke, "Constitutive model for the triaxial behavior of concrete," in: Proc. of the Int. Association for Bridge and Structural Engineering, ISMES, Bergamo (1975), Vol. 19, p. 174. 
[9] Rots JG (1991) Numerical simulation of cracking in structural masonry. Heron 36(2):49-63

[10] IS: 2185 (part 1)-1979 Specification for concrete masonry units. BIS Publication, New Delhi.

[11] IS: 2250-1981 Code of practice for Masonry mortars. BIS Publication, New Delhi

[12] IS: 1905-1987 Code of practice for structural use of unreinforced masonry. BIS Publication, New Delhi.

[13] IITK-GSDMA guidelines for structural use of reinforced masonry, National Information Center for Earthquake Engineering Department of Civil Engineering, Indian Institute of Technology Kanpur 208016. 